https://doi.org/10.37208/tgn27308

\section{Observations of two species of clearwing moths (Sesiidae) in south- west Scotland during 2019}

\section{C.J. McInerny}

School of Life Sciences, University of Glasgow, Glasgow G12 8QQ

E-mail: chris.mcinerny @ glasgow.ac.uk

The clearwings (Sesiidae) are day flying moths with fragmented and restricted distributions in Scotland and the U.K., although they are likely under-recorded (Waring et al., 2009). They are notable for their Batesian mimicry, both in appearance and behaviour, of various species of wasps (Hymenoptera). Up to 16 species have been recorded in Britain, but with just five being seen in Scotland, and these rarely encountered because of their elusive nature (Randle et al., 2019). However, the development of pheromone lures has greatly aided their detection (Larsson, 2016; Anglian Lepidopterist Supplies, 2020a).

The Welsh clearwing (Synanthedon scoliaeformis) has a very limited distribution across the U.K., observed at just a few sites in England, Wales and Scotland (Randle et al., 2019). In Scotland it has been reported from a location in Sutherland, at Glen Affric, Glen Moriston and Rannoch Moor, all Highland, and the Trossachs, Stirlingshire (Bland, 1991; Barbour \& Bland, 1997; Knowler, 2009; Randle et al., 2019).

During both 2017 and 2018 I attempted to detect the species in the Trossachs at various sites near Aberfoyle previously identified by John Knowler using the SCO pheromone (Anglian Lepidopterist Supplies, 2020a), with no success. However, in 2019 , on 27 th June, on a sunny, warm day a number of individuals came to pheromone at one location. Over the course of two hours, from 8.30-10.30 a.m., up to 100 visitations of Welsh clearwings occurred, in groups of up to four individuals (Fig. 1). The first appeared almost immediately after the pheromone lure was removed from its container and was hung in a gauze bag on a low branch of a birch tree (Betula sp.). Individuals or groups would fly towards the lure, briefly "touch" the gauze bag or a nearby branch a few times, and then fly rapidly away. It was not determined whether the same individuals returned multiple times, or if the visits over the period represented different moths; it has been suggested that males can move large distances (Knowler, 2009). But it seems likely that many clearwings were present, with 27 th June representing an emergence day for the species in the clement weather.

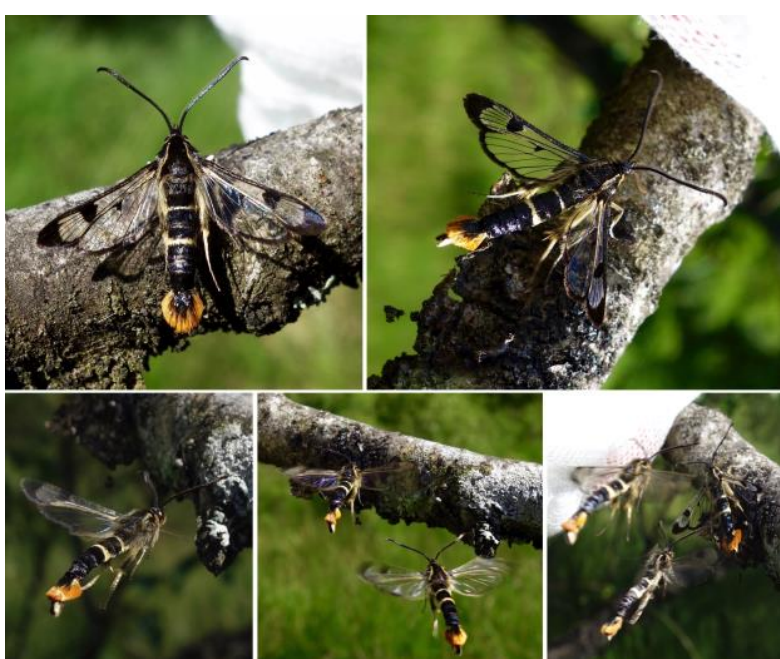

Fig. 1. Welsh clearwings (Synanthedon scoliaeformis), near Aberfoyle, the Trossachs, Stirlingshire, Scotland, 27th June 2019. Forewing length $c a$. $15 \mathrm{~mm}$. The white gauze bag containing the pheromone lure used to attract the moths is visible in three of the images. (Photos: C.J. McInerny)

The thrift clearwing (Pyropteron muscaeforme) has a limited distribution in Scotland and is found only in coastal areas in the south-west and north-east, associated with stands of sea thrift (Armeria maritima), the moth's foodplant (Randle et al., 2019). Luring with the pheromone HYL (Anglian Lepidopterist Supplies, 2020a) by Martin Culshaw and the author detected one individual on the beach at Brighouse Bay, Kirkcudbright, Dumfries and Galloway on 13th July 2019 at 1 p.m. amongst sea thrift (Fig. 2). Only one was observed, although many beach sites along the Dumfries and Galloway coast with sea thrift were surveyed over the course of two days.

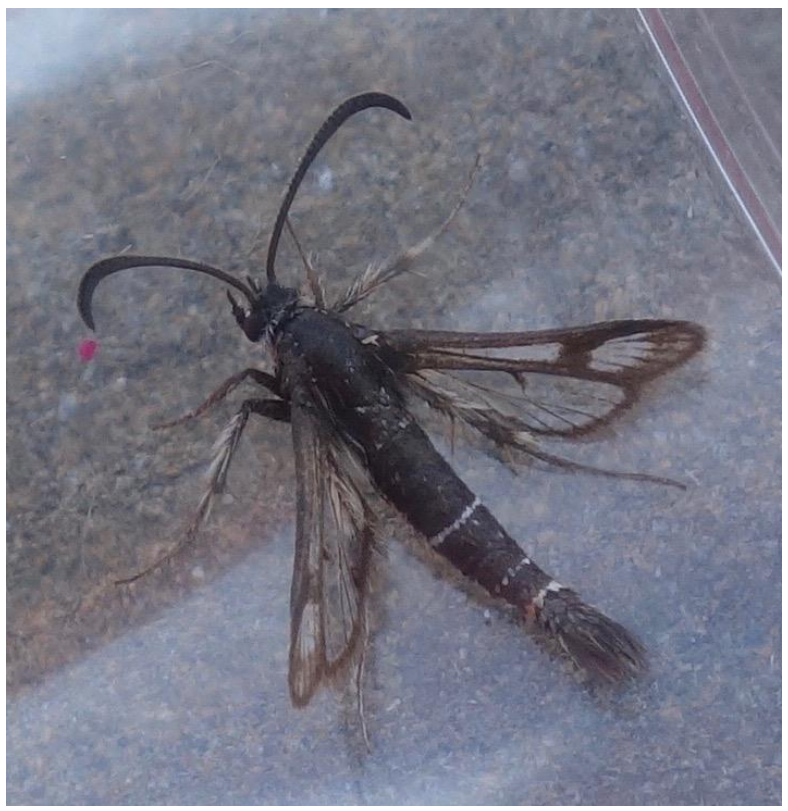

Fig. 2. Thrift clearwing (Pyropteron muscaeforme), Brighouse Bay, Kirkcudbright, Scotland, 13th July 2019. Forewing length $c a .8 \mathrm{~mm}$. (Photo: C.J. McInerny) 
As this Short Note has illustrated, pheromone luring is an effective strategy for identifying locations containing clearwing moths, which would otherwise be extremely difficult to find. Guidance notes have been published on their use (Anglian Lepidopterist Supplies, 2020b), but a brief summary is presented here in the context of southwest Scotland.

An important consideration when searching for moths is knowledge of their flight period, which can be ascertained from published sources, such as Randle et al. (2019). Weather conditions are also significant with both of these day flying clearwing moths active in sunny conditions. Light winds are helpful to distribute the pheromone to attract moths, the recommendation being that the pheromone is exposed for 30 minutes at each site, before a negative record is noted.

Finally, ethical considerations are very important to consider when using pheromones, particularly for moth species such as clearwings, some of which are rare and have legal protection (Anglian Lepidopterist Supplies, 2020 b). It is strongly recommended that sites are surveyed with pheromone only once in a season, and that precise locations are not advertised by social media or in publications. It is for these reasons that precise locations are not listed in this Short Note, though they have been lodged with the moth recorders for the appropriate vice-counties.

I would like to acknowledge the inspiration and advice of the late John Knowler, which led me to see the stunning Welsh clearwing; and the companionship and perseverance of Martin Culshaw that allowed our discovery of the thrift clearwing. I also acknowledge the very helpful comments of the reviewer, Paul Tatner, which much improved the text.

\section{REFERENCES}

Anglian Lepidopterist Supplies (2020a). https://www.angleps.com/pheromones.php Accessed 17th May 2020.

Anglian Lepidopterist Supplies (2020b). Guidance Note on the Use of Pheromone Lures for Recording Moths https://www.angleps.com/A_Brief_Guidance_Note _on_the_use_of_Pheromone_Lures_for_Recording _Moths.pdf

Barbour, D. \& Bland, K. (1997). Distribution of the Welsh clearwing Synanthedon scoliaeformis in Scotland. Entomologist's Gazette 48, 93.

Bland, K. (1991). The Welsh clearwing Synanthedon scoliaeformis (Borkhausen) (Lepidoptera: Sesiidae), still present in its Sutherland locality. Entomologist's Gazette 42, 184.

Knowler, J.T. (2009). The Welsh clearwing in the Trossachs. The Glasgow Naturalist 25(1), 89-90.

Larsson, M.C. (2016). Pheromones and other semiochemicals for monitoring rare or endangered species. Journal of Chemical Ecology 42, 853-868. https://doi.org/10.1007/s10886-016-0753-4

Randle, Z., Evans-Hill, L.J., Parsons, M.S., Tyner, A., Bourn, N.A.D., Davis, T. et al. (2019). Atlas of
Britain \& Ireland's Larger Moths. Pisces Publications, NatureBureau Ltd., Newbury.

Waring, P., Townsend, M. \& Lewington, R. (2009). Field Guide to the Moths of Great Britain and Ireland. (2nd edition). British Wildlife Publishing Ltd., Dorset. 